\title{
Physicochemical, Microstructural, Mineralogical and Thermal Properties of Owukpa Coal
}

Bemgba B. Nyakuma ${ }^{1}$, Edo O. Ojoko², Olagoke Oladokun ${ }^{1}$, Olasunkanmi O. Olapeju³, Adakole B. Aboje ${ }^{4}$

${ }^{1}$ Department of Chemical Engineering, Faculty of Chemical \& Energy Engineering, Universiti Teknologi Malaysia, 81310 Skudai, Johor Bahru, Malaysia.

${ }^{2}$ Department of Building Technology, School of Environmental Studies, Federal Polytechnic Nasarawa, Nasarawa State, Nigeria.

${ }^{3}$ Department of Urban and Regional Planning, Universiti Teknologi Malaysia 81310 Skudai, Johor Bahru, Malaysia.

${ }^{4}$ Ehinehi Nigeria Enterprises Limited, 11 Crescent, Flat 130 Kado Estates, Federal Capital Territory, Abuja, Nigeria.

\section{Correspondence Email: bbnyax1@gmail.com, bnbevan2@live.utm.my}

\begin{abstract}
Coal currently accounts for over $38 \%$ of electric power generation around the globe. Hence, it is a significant critical contributor to socio-economic growth and development, particularly in the BRIC economies. The success of the coal energy in these nations in addition to the discovery of vast new coal deposits have revived Nigeria's interest in coal power. However, there is lack of comprehensive data on the pollution emission profiles, along with the physicochemical, thermal, and kinetic properties of Nigerian coals as required for power plant operations. Therefore, this paper presents preliminary findings on the physicochemical, microstructural, mineralogical and thermal properties of Owukpa (WKP) coal from Benue State in Nigeria. The results showed that WKP contains high compositions of combustible elements and heating value but low pollutant elements. Furthermore, thermal degradation revealed high conversion efficiencies particularly under oxidative conditions as required for electric power generation through combustion.
\end{abstract}

Keywords: Fuel Characterisation, Thermal Degradation, Owukpa, Benue, Nigeria. 


\section{Introduction}

Currently, coal accounts for $38 \%$ of global electricity generation [1]. It is the most widely abundant and accessible source of fossil energy around the globe. As a result, coal energy is a significant critical contributor to socio-economic growth and development, particularly in emerging economies such as India and China [2]. Furthermore, coal has played an immense role in addressing energy poverty in the BRIC nations particularly South Africa where coal accounts for about $80 \%$ of electric power generation [3]. The success of South Africa's coal industry in addition to the discovery of new coal deposits have revived interest in Nigeria's coal industry. However, the contribution of coal to Nigeria's power generation is nonexistent [4] despite the nation's 3 billion tonnes of coal reserves $[5,6]$. This is attributed to numerous challenges particularly lack comprehensive data on the physicochemical, thermal and kinetic properties of Nigerian coals required for the design and operation of coal power plants [7-9]. As a result, large coal deposits remain unutilized in Benue, Nasarawa, Kogi and other states in Nigeria. Therefore, this study seeks to examine the physicochemical, microstructural, mineralogical and thermal properties characterisation of Owukpa (WKP) and present some preliminary findings on the coal for future power generation.

\section{Experimental}

The ultimate, proximate and calorific analyses of the coal sample were examined to determine its elemental, fuel and heating value properties. Furthermore, the functional group analysis was examined by Fourier Transform Infra-Red (FTIR) spectroscopy through the Shimadzu Prestige 21 FTIR-ATR analyser. The microstructure and mineralogy were examined by Scanning Electron Microscopy and Energy Dispersive X-ray (SEM/EDX) analyses. The procedure for SEM/EDX is described in our previous study [10]. Lastly, the thermal degradation behaviour and characteristic profile temperatures (TPC) were examined by nonisothermal thermogravimetric analysis (TGA) by heating $18 \mathrm{mg}$ of sample in an alumina crucible from $30{ }^{\circ} \mathrm{C}$ to $900{ }^{\circ} \mathrm{C}$ at a heating rate of $50{ }^{\circ} \mathrm{C} / \mathrm{min}$ on the Shimadzu TG-50 analyser under air and nitrogen gas for flash combustion (FCO) and pyrolysis (FPY), respectively. This 
was aimed at simulating the thermal degradation behaviour of the coal during power plant conversion.

\section{Results and Discussion}

The physicochemical analyses revealed the Owukpa coal contains high proportions of the combustible elements; carbon $(\mathrm{C})$, hydrogen $(\mathrm{H})$, and oxygen $(\mathrm{O})$ for thermal conversion. The composition of $\mathrm{C}, \mathrm{H}$ and $\mathrm{O}$ were; 65.39 wt.\%, 5.25 wt.\% and 27.25 wt.\%, respectively. However, the composition of the pollutant elements nitrogen (N) and sulphur (S) were 1.59 wt.\% and $0.51 \mathrm{wt} . \%$. The calorific value of Owukpa was $26.68 \mathrm{MJ} / \mathrm{kg}$ which indicates it is a subbituminous, non-agglomerating, and low-rank coal (LRC). Furthermore, the heating value of WKP is significantly higher than other Nigerian coals from Garin Maiganga (23.74 MJ/kg) [9], Inyi (19.39 MJ/kg), Ezimo (20.96 MJ/kg) [5], Ihioma (19.40 MJ/kg) and Ogboligbo (15.55 $\mathrm{MJ} / \mathrm{kg})[2,7]$. However, the results are in fairly good agreement with the $\mathrm{HHV}$ of $26.51 \mathrm{MJ} / \mathrm{kg}$ reported for WKP by Chukwu et al., [5]. The SEM/EDX revealed the microstructure of WKP coal is comprised of a heterogeneous mix of fine and coarse-grained particles rich in organic and metallic elements. The major elements detected by EDX analysis were; carbon ( $C=82.74$ wt.\%), oxygen ( $\mathrm{O}=15.29 \mathrm{wt} . \%)$, silicon ( $\mathrm{Si}=0.90 \mathrm{wt} . \%)$ and aluminium ( $\mathrm{Al}=0.43 \mathrm{wt} . \%)$.

The TGA analysis revealed that flash combustion (FCO) of WKP resulted in $77.41 \%$ mass loss whereas for the flash pyrolysis (FPY) process it was 42.09\%. Based on the results of the thermal degradation, the characteristic temperature profiles (TPCS) were examined for the flash conversion of the coal sample. The thermal degradation of WKP during FCO occurred in the temperature range of $274.9{ }^{\circ} \mathrm{C}$ to $759.2^{\circ} \mathrm{C}$ with a midpoint temperature of $519.5^{\circ} \mathrm{C}$. However, the thermal degradation during FPY occurred in the temperature range of 339.1 ${ }^{\circ} \mathrm{C}$ to $617.3{ }^{\circ} \mathrm{C}$ with a midpoint temperature of $469.4{ }^{\circ} \mathrm{C}$. Consequently, the solid residual mass yields for the FCO and FPY were; $22.59 \%$ and 57.91\%, representing ash and coke, respectively. This indicates the FCO resulted in higher conversion of the coal compared to the FPY process. 


\section{Conclusion}

The results indicate Owukpa coal contains high proportions of combustible elements and low proportions of pollutant precursor elements. The proximate analysis revealed low moisture and volatiles content but high ash, fixed carbon and calorific value. The microstructural and mineralogical analyses revealed WKP contains metal elements which can be beneficial as catalysts during thermal conversion. The thermal analyses revealed flash combustion (FCO) is a more thermally efficient approach for energy recovery from Owukpa coal. Lastly, the results showed that Owukpa might be well suited for electric power generation and cement manufacture.

\section{References}

[1] IEA. (2017). Market Series Report: IEA Coal 2017 Analysis and Forecasts to 2022: 1-8.

[2] Nyakuma, B.B., O. Oladokun, A. Jauro, and D.D. Nyakuma. (2017). Evaluating the Energy Recovery Potential of Nigerian Coals under Non-Isothermal Thermogravimetry. IOP Conference Series: Materials Science and Engineering, 217(1): 012013.

[3] Shahbaz, M., A.K. Tiwari, and M. Nasir. (2013). The effects of financial development, economic growth, coal consumption and trade openness on $\mathrm{CO} 2$ emissions in South Africa. Energy Policy, 61: 1452-1459.

[4] WorlBank. Access to electricity (\% of the population) - The case of Nigeria. 2018; Available from https://bit.ly/2/h1b8L.

[5] Chukwu, M., C. Folayan, G. Pam, and D. Obada. (2016). Characterization of some Nigerian coals for power generation. Journal of Combustion, 2016.

[6] Ohimain, E.I. (2014). Can Nigeria generate $30 \%$ of her electricity from coal? International Journal of Energy and Power Engineering, 3(1): 28-37.

[7] Nyakuma, B.B., O. Oladokun, A. Jauro, and D.D. Nyakuma. (2017). Fuel Characterization of Newly Discovered Nigerian Coals. IOP Conference Series: Materials Science and Engineering, 217(1): 012012. 
[8] Nyakuma, B.B. and A. Jauro. (2016). Chemical and Pyrolytic Thermogravimetric Characterization of Nigerian Bituminous Coals. GeoScience Engineering, 62(3): 1-5.

[9] Nyakuma, B.B. and A. Jauro. (2016). Physicochemical Characterization and Thermal Decomposition of Garin Maiganga Coal. GeoScience Engineering, 62(3): 6-11.

[10] Nyakuma, B., A. Jauro, O. Oladokun, A. Bello, H. Alkali, M. Modibo, and M. Abba. (2018). Physicochemical, Mineralogical, and Thermogravimetric Properties of Newly Discovered Nigerian Coals. Petroleum \& Coal, 60(4): 641-649. 